
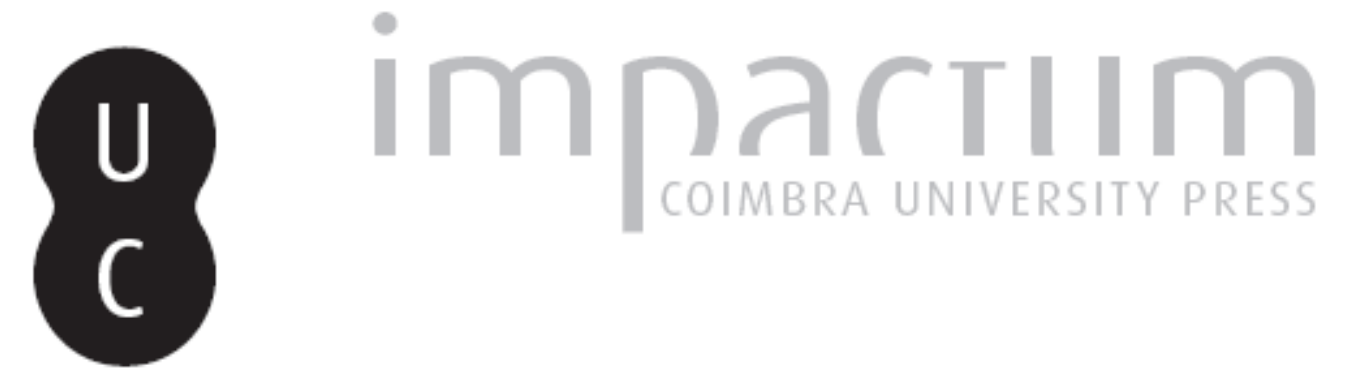

\title{
How arithmetic is useful for understanding the Good as the principle of forms in Plato's Republic
}

Autor(es): $\quad$ Yang, Moon-Heum

Publicado por: Imprensa da Universidade de Coimbra

URL persistente:

URI:http://hdl.handle.net/10316.2/42186

DOI:

DOI:https://doi.org/10.14195/2183-4105_11_7

Accessed : $\quad$ 26-Apr-2023 12:01:59

A navegação consulta e descarregamento dos títulos inseridos nas Bibliotecas Digitais UC Digitalis, UC Pombalina e UC Impactum, pressupõem a aceitação plena e sem reservas dos Termos e Condições de Uso destas Bibliotecas Digitais, disponíveis em https://digitalis.uc.pt/pt-pt/termos.

Conforme exposto nos referidos Termos e Condições de Uso, o descarregamento de títulos de acesso restrito requer uma licença válida de autorização devendo o utilizador aceder ao(s) documento(s) a partir de um endereço de IP da instituição detentora da supramencionada licença.

Ao utilizador é apenas permitido o descarregamento para uso pessoal, pelo que o emprego do(s) título(s) descarregado(s) para outro fim, designadamente comercial, carece de autorização do respetivo autor ou editor da obra.

Na medida em que todas as obras da UC Digitalis se encontram protegidas pelo Código do Direito de Autor e Direitos Conexos e demais legislação aplicável, toda a cópia, parcial ou total, deste documento, nos casos em que é legalmente admitida, deverá conter ou fazer-se acompanhar por este aviso.

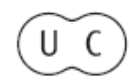




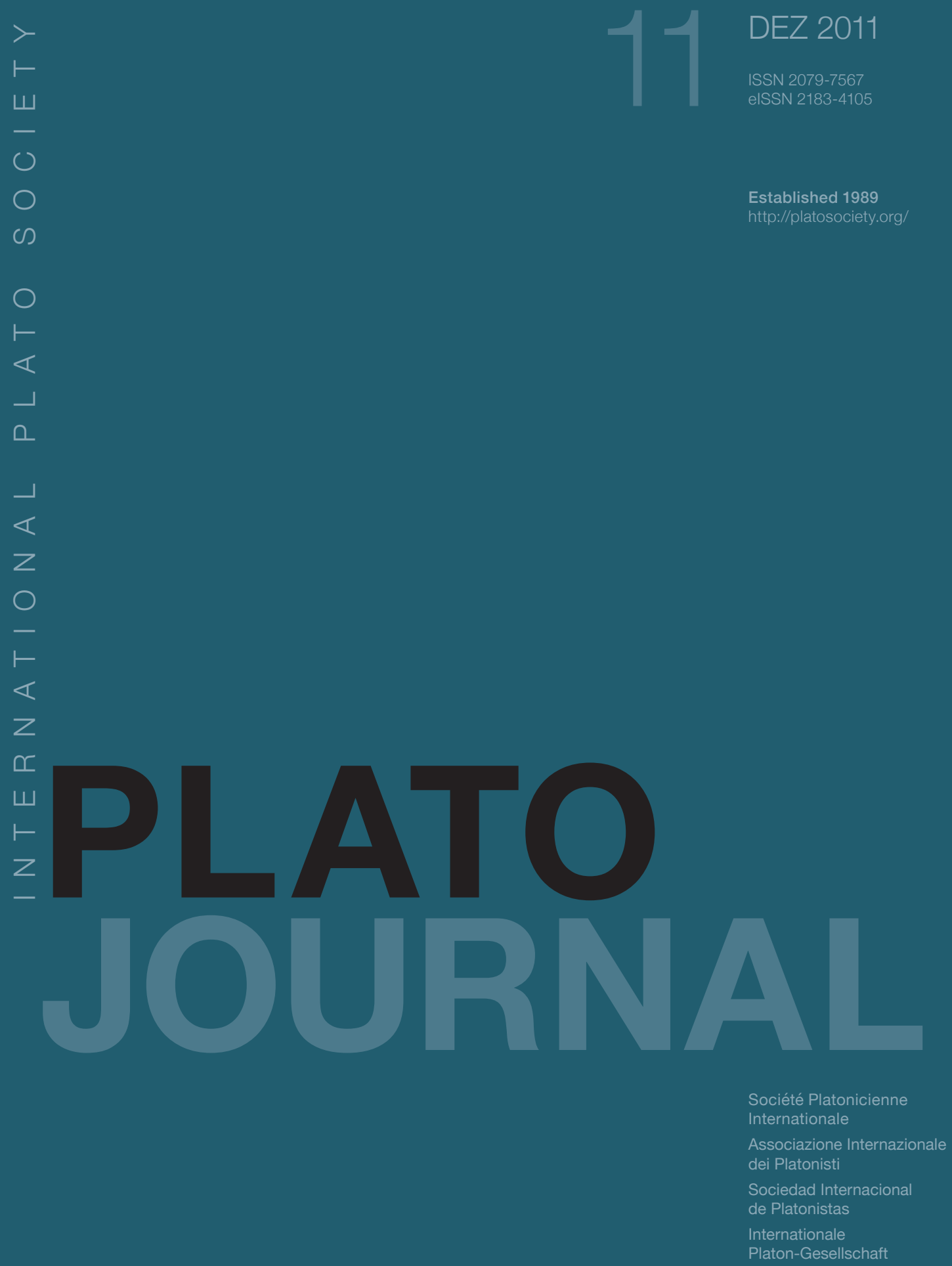




\title{
HOW ARITHMETIC IS USEFUL FOR UNDERSTANDING THE GOOD AS THE PRINCIPLE OF FORMS IN PLATO'S REPUBLIC
}

\author{
Prof. Moon-Heum Yang
}

I.

Many readers might be surprised at the title, since most of the traditional discussions have focused not on the relation of arithmetic to the Good, but on the relation of mathematics to the Good. But I have to point out that this traditional approach tends not to pursue seriously a specific way in which the five mathematical sciences (arithmetic, plane geometry, solid geometry, astronomy and harmonics) are closely related. And obviously, it is because of "a synoptic view of their [the five sciences'] kinship with one another" (537c), which I shall call the thesis of synopsis, that the study of the sciences "contributes something to our goal [of reaching the Good]" (531d). I have not yet read, so far as I am aware, any serious attempt to base the synoptic view on arithmetic, much less any attempt to approach the Good as the principle of Forms accordingly. Although Plato is not explicit about the way arithmetic should be the key to the kinship in question, there are some significant suggestions, one of which is as follows: "the common thing which is used by all crafts, all modes of thought, and all sciences, and which everybody of necessity must learn to begin with" is "number and calculation" (522c1-7). Let me call this the thesis of the general application of arithmetic. We are further told that the man who is "good at calculation (logistikos)" is naturally good at every other study (526b), and that the theoretical sciences of arithmetic and geometry help see "the Form of the Good" (526e). In my study, the two theses mentioned, the thesis of synopsis and that of the general application of arithmetic, constitute the basis on which to expound the relationship between arithmetic and the Good.

In the next section, I shall distinguish carefully two aspects of arithmetic, i.e. method and science. The former aspect, related to the thesis of the general application of arithmetic, reveals the necessity of using number in dealing with Forms. The latter, on the other hand, related to the thesis of synopsis, is

PLATO, The electronic Journal of the International Plato Society, n 11, 2011.

http://gramata.univ-paris1.fr/Plato/article104.html

(c) All rights of reproduction of any form reserved. 
YANG, Moon-Heum, « Why Arithmetic is useful for understanding the Good as the Principle of Forms in Plato's Republic »

concerned with the nature of numbers. In the third section, I shall focus on the thesis of synopsis. In the fourth and last section, I will pursue the relation between arithmetic and the Good.

\section{Arithmetic as Method and Science}

Let me first expose arithmetic as method implied in the treatment of the well-known example of three fingers (523c). It is assumed that since the fingers are adequately apprehended by the sense of sight, the soul is not compelled to ask the intelligence what a finger is (523d). But the same finger in different relations appears as big and small, hard and soft, and so on. In such confused perceptions, the soul will attempt, by calling upon "calculation and intelligence", to examine "whether each of the things announced to it is one or two" (524b3-5). Immediately after this occurs the following passage (524b7-524c2):

(i) If they appear to be two, each appears as different and one. Yes.

(ii) If each is one while both are two, it will think of the two as separate, for if they were not separate, it would not be thinking of them as two, but as one. Correct.

"Calculation" or, more precisely, counting refers to the intelligence's act. Thus, the passage describes how it uses number in separating such things as the big and small. Now, since when the things in question are separate from each other, "it first occurs to us to ask what the big is and what the small is" (524c10-11), it seems reasonable to suppose that the big and the small here should refer to Forms, as will be confirmed soon. In this regard, it is worth noting that by proving the essential role of number in separating Forms, Plato obviously suggests the possibility of counting Forms. To this point I shall return in the last section.

We find another passage which suggests the necessity of using number in the treatment of Forms (475e9-476a7).

Since the beautiful is the opposite of the ugly, they are two.

Of course.

And since they are two, each is one? I grant that also.

PLATO, The electronic Journal of the International Plato Society, n 11, 2011.

http://gramata.univ-paris1.fr/Plato/article104.html

(c) All rights of reproduction of any form reserved. 
And the same account is true of the just and the unjust, the good and the bad, and all the Forms. Each of them is itself one, but because they manifest themselves everywhere in association (koinonia) with actions, bodies, and one another, each of them appears to be many. That's right.

This passage, known as providing the remarkable fact of the co-existence of one and many in Forms, is obviously different from the previous one, at least in one point. The respective opposite Forms are "two" regardless of counting or calculating: From the fact that they are opposite is deduced the fact that they are two, and from this the fact that each is one. Of particular interest, in this connection, is the fact that by combining the one- many notion with "all the Forms," Plato clearly suggests that number is logically involved in investigating the separate Forms. To this striking suggestion I shall return in the last section.

It is now time to deal with arithmetic as science before examining how it is related to the understanding of the Good. This subject requires the nature of mathematical objects, but let it suffice to point out that for Plato the objects are different from Forms in nature, as I have discussed in detail elsewhere ${ }^{1}$. We can confirm the same thought in the treatment of arithmetic in Bk. VII. A sensible unit is both one and an infinite number (that is, self-contradictory) so that if the unit has this quality, every number has it too (525a). As the conspicuous coexistence of unity and multiplicity in such a unit indicates, there is only one way for establishing an intelligible number without involving contradiction, which is to construct it from self-identical units: as the arithmeticians at 526a3-4 claim, "every unit is equal to every other without the smallest difference, and contains no parts." No doubt, the (plural) indivisible and equal units cannot be Forms, nor can "the numbers themselves" (525d) constructed from such units, and evidently, such numbers must be likewise contradiction-free. This explains why the two expressions, "the unit itself" at 524e and "the numbers themselves" at 525d, should refer not to metaphysical Forms but to pure arithmetical objects. Thus, arithmetic requires not only a plurality of pure units, but also a plurality of pure numbers, which entails that the objects cannot be unique Forms. I now turn to setting out my own account of the thesis of synopsis.

\footnotetext{
${ }^{1}$ See Yang (1), (2).
}

PLATO, The electronic Journal of the International Plato Society, n 11, 2011.

http://gramata.univ-paris1.fr/Plato/article104.html

(c) All rights of reproduction of any form reserved. 


\section{The thesis of synopsis}

Let me begin with the sequence of the five studies in the order of arithmetic, plane geometry, solid geometry, astronomy and harmonics. Careful reading of the relevant passages shows that Socrates in the Republic is made to begin with plane surfaces in the theoretical construction of the geometrical and astronomical objects. Quite interestingly, the same sort of beginning is found at Timaeus 53 cff., where the triangle is disclosed as the most basic element in the theoretical construction required. Thus, we need to specify the respect in which numbers, the objects of arithmetic, are required in the theoretical construction of the objects with which a theoretical science such as geometry and astronomy is concerned. And the respect indicated deserves explicit treatment for elucidating the thesis of synopsis. What is central in this treatment should be the notion of measure (metron). In ordinary life, we select a unit of measurement - foot, inch, gram, or pound, as the case may be - to which measure 1 is assigned, and count the number of the units making up the quantity in question. But here, as Aristotle points out, "we treat as indivisible the line a foot long" (Met, 1052b3233 ), although it is actually divisible. Thus, "it is not in the same way that every 'one' is indivisible, e.g. a foot and a unit" (Met, 1053a21-22). "Where it is thought impossible to take away or to add, there the measure is exact (hence that of number is most exact; for we posit the unit as indivisible in every aspect); but in all other cases we imitate this sort of measure" (Met. 1052b35-1053a2).

Aristotle's notion of metron based on the imitation relation throws light on the way arithmetic can unify other mathematical sciences: Plato can unify them by making each of them, in its pursuit, assume a unit functioning as metron. And this is exactly what we can recognize in the Republic's and Timaeus' construction of the theoretical objects. Let me first examine the Timaeus' view of it for a clearer understanding of the Republic's view of it. The Timaeus' description of Chaos (52d-53c) is the description of the world of the four primary kinds "without proportion or measure"(53a8). Thus, when the god gives the kinds a distinct configuration by means of "shapes and numbers" (53b5), what is meant is the theoretical construction of the regular solids corresponding to the four primary bodies. Certainly, these 'shapes' represent the solids to be constructed. However, no special reference is found to the need for constructing these 'numbers'. Thus, since the shapes are constructed on the basis of the prior

PLATO, The electronic Journal of the International Plato Society, n 11, 2011.

http://gramata.univ-paris1.fr/Plato/article104.html

(c) All rights of reproduction of any form reserved. 
YANG, Moon-Heum, « Why Arithmetic is useful for understanding the Good as the Principle of Forms in Plato's Republic »

(theoretical) construction of the indivisible triangle, this triangle is assumed as a unit functioning as metron so that 'number of units' in this case may mean 'number of indivisible triangles'. Remarkably, as is confirmed at Timaeus 54d, after the indivisible triangle has been constructed, we read: "Let's next explain what sort of figure each body has, and the numbers that combine to compose it." ${ }^{2}$ It is, therefore, quite reasonable to suppose that the numbers in "shapes and numbers" are the ones to be defined, as in the Republic, as a plurality of units.

The same approach is found in the Republic, although Plato does not make himself as explicit as could be desired. Let me first point out that the method of using 'problems' is commonly attributed to geometry, astronomy, and harmonics (530b, 531c). The problem, in its technical sense, is concerned with constructing intelligible figures and solids. The need for constructing them is raised by contradictions or inexactitudes to which 'use of sensible objects' leads. It is also important to note that the method essentially requires number or ratio $(529 \mathrm{~d}-\mathrm{e}$, 531c), which indicates the necessity of finding a unit functioning as metron. In this way, we find some significant parallels in constructing intelligible objects between the two dialogues. Thus, when Socrates in the Republic is made to insert solid geometry between plane geometry and astronomy (dealing with the intelligible solid objects in motion), the reason the construction of the required objects was not dealt with in more detail may be that the discipline, as the passage at 528b-c suggests, was not well established when Plato wrote the dialogue.

As the above shows, serving as a model capable of positing the unit as absolutely indivisible, arithmetic is essential in the search for the kinship of the sciences. Thus, the thesis of synopsis requires that the arithmetical unit should pervade the methods of the other sciences, so that a discipline such as plane geometry and solid geometry assumes something analogous to the unit, and counts the number of lines, squares, and so forth. So, the thesis of synopsis is based on the thesis of the general application of arithmetic, when 'arithmetic' is understood as a branch of mathematics. However, the latter thesis is ambiguous,

\footnotetext{
${ }^{2}$ For a detailed discussion of "the numbers that combine to compose it," see Brisson, pp. 357-391.

${ }^{3}$ Here let me point out that theoretical harmonics in the Republic, unlike theoretical geometry and astronomy, deals with pure numbers, and is concerned with problems concerning "which numbers are consonant and which are not, and what is the reason in each case" (531c).
}

PLATO, The electronic Journal of the International Plato Society, n 11, 2011. http://gramata.univ-paris1.fr/Plato/article104.html

(c) All rights of reproduction of any form reserved. 
YANG, Moon-Heum, « Why Arithmetic is useful for understanding the Good as the Principle of Forms in Plato's Republic »

since arithmetic or numbers should also apply to Forms, as will be made clearer as the discussion proceeds.

\section{Arithmetic and the Good}

To establish the synoptic view by means of arithmetic and to establish the relationship between arithmetic and the Good should be two quite different things. However, the fact that the synoptic view is required just for understanding the Good makes us examine the relevant passages in the Republic and other dialogues to pave the way for establishing the relationship between arithmetic and the Good. But this cannot be the place to enter into a detailed discussion of the nature of the Good. This question is too large to discuss here. My concern is rather with exploring a specific context in which arithmetic should be useful or required for the understanding of the Good as the principle of Forms. In the absence of Plato's explicit account of the role of arithmetic in this scheme, the subject will remain to a certain extent unclear. Nonetheless, despite vexing uncertainties, it ought to be possible to expose a few of the basic issues with a view to provoking further discussion of them.

In my study, the most important thing to consider is that arithmetic as science deals with numbers, when a number is defined as a plurality of units, and that this definition in arithmetic is the key to the search for the kinship of the sciences. So, my question comes to this: What is the relevance of the arithmetical definition, among other things, to the dialogue's theory of Forms related to the Good, when we are told that a synoptic view of the kinship will contribute to the understanding of the Good?

Seeking the relevance in question, I assume that Plato, just as the arithmeticians at 526a3-4 do, will postulate an unlimited number of indivisible Forms. In this regard, I refer to two postulations both at Philebus 15a4-5 and at $56 \mathrm{e}$-3. In the former, postulating (tithesthai) "man as one, or ox as one, or the beautiful as one, or the good as one," Socrates characterizes them as "units (monadas) in the strict sense"(14b1-2). It is on the basis of this postulation that Socrates enters into the method of Division (15d-17a). In the latter postulation, on the other hand, Socrates, just as in the Republic, postulates (thêsei) an

PLATO, The electronic Journal of the International Plato Society, n 11, 2011.

http://gramata.univ-paris1.fr/Plato/article104.html

(c) All rights of reproduction of any form reserved. 
YANG, Moon-Heum, « Why Arithmetic is useful for understanding the Good as the Principle of Forms in Plato's Republic »

unlimited field of absolutely equal and indivisible units of arithmetic. Now it is perfectly fair to suppose that the postulation at Philebus 15a4-5 should be read as including a large number of Forms (as units), as is obvious from the context of the method of Division. And by this we can achieve a proper balance between the two postulations. Moreover, the postulation of a large number of Forms fits in with the Republic's theory of Forms, since it is implied at Republic 509b, where the Good should be the cause of the being of the other Forms.

Careful comparison of the two postulations in the Philebus shows that they allude to the two following related things: (i) just as arithmeticians construct number in a definite way on the basis of their postulation, so dialecticians should have a definite theory for explaining number on the basis of the "monads in the strict sense", and (ii) Setting up such a theory on their part is inherently related to the method of (Collection-) Division. When I say 'theory', what I have in mind is that while arithmetical units are absolutely equal and without content, each Form is unique in content so that the notion of 'number of Forms' requires special explanation. We find no explicit theory for that in the Philebus, although the notion of 'a definite number of species' is essential to the method of Division (15d-17a). The Republic also requires such a theory apart from the postulation of an enormously large number of Forms. We may recall the two important points recognized in the second section in connection with arithmetic as method: (as the three fingers passage shows) the rational soul counts Forms, and (as the koinonia passage shows) the one-many notion (implying the notion of number) is logically involved in the association of Forms themselves.

Trying to bring out clearly the relation of number to the method of Collection-Division in the Republic, I notice that the statement of the thesis of synopsis, "a synoptic view (synopsis) of their kinship with one another..." (537c), is immediately followed by the declaration: "the man who can achieve a synoptic vision (synoptikos) is a dialectician" (537c). This makes us think about the meaning of the words, synopsis and synoptikos, in the case of Forms. On my view, in accordance with its primary meaning ('a seeing all together,' 'general view'), the term synopsis may be very plausibly related to the term synhoran ('to see together',

\footnotetext{
${ }^{4}$ This explanation may require pure arithmetical Forms such as twoness, threeness, and also Plato's theory of metechein.
}

PLATO, The electronic Journal of the International Plato Society, n 11, 2011. http://gramata.univ-paris1.fr/Plato/article104.html

(c) All rights of reproduction of any form reserved. 
YANG, Moon-Heum, « Why Arithmetic is useful for understanding the Good as the Principle of Forms in Plato's Republic »

'to comprehend') occurring with the method of Collection (Phdr. 265d). In the case of mathematics, we have seen that the search for the kinship of the various sciences was made possible by securing a unifying principle of them. We can thus see a remarkable similarity between this and the method which "consists in seeing together widely scattered things and collecting them (species) into one kind (a single Form)"(Phdr. 265d).

With this preliminary discussion we now come to the passage at Republic $511 \mathrm{~b}-\mathrm{c}$ in Bk. VI, where the 'way up' and 'way down' in connection with Collection and Division is clearly suggested. Thus, when in the ascent the reason itself ascends step by step to "the unhypothetical first principle of all", it is implied that each Form should be understood by reference to every other, and be subsumed under higher and yet higher Forms. In the descent, on the other hand, the reason itself, "keeping hold of what follows from it [the first principle]", "comes down to a conclusion without making use of anything visible at all, but proceeding by means of Forms and through Forms to its conclusion which are Forms." Certainly, the Republic is not interested in attempting an exhaustive classification of Forms, nor is there any dialogue in which Plato attempts such a classification. However, reading Collection and Division in the Republic, we see a strict condition placed on classification in a crucial way: in a Collection moving upwards or in a Division moving downwards, when genera and species are found, the numbers both of the former and of the latter should be determined. The importance of this thought is obvious: inquiry into 'bow many each One (genus or species) is' is required for a systematic understanding of the Forms. Or, to put it in another way, their structure is arithmetical. Arriving at this conclusion, let me stress that the Republic passage referred to in Bk. VI is continuous with Bk. VII in which the thesis of synopsis is treated in relation to the Good, as is clearly understood when we rightly identify the unhypothetical first principle of all with the Form of the Good. And I have pursued in some detail how that thesis leads us to notice that number is closely related to Collection and Division.

The above is my exploration of a specific context in which arithmetic is useful or required for understanding the Good, without attempting to amplify Plato's view of the principle. Surely, that calls for elucidating Plato's theory of number for Forms. However, any treatment of the subject with the seriousness it

PLATO, The electronic Journal of the International Plato Society, n 11, 2011.

http://gramata.univ-paris1.fr/Plato/article104.html

(c) All rights of reproduction of any form reserved. 
YANG, Moon-Heum, « Why Arithmetic is useful for understanding the Good as the Principle of Forms in Plato's Republic »

deserves would take us beyond the scope of this study. My basic view on this ${ }^{5}$ is that Sextus Empiricus' comment is right according to which when a Form as a unity, embracing other Forms, is said to be two or three or four, there should be number by participation in which two or three or yet higher numbers are predicated of them.

Dongguk University, Korea.

${ }^{5}$ See Yang(3)

PLATO, The electronic Journal of the International Plato Society, n 11, 2011.

http://gramata.univ-paris1.fr/Plato/article104.html

(c) All rights of reproduction of any form reserved. 
YANG, Moon-Heum, « Why Arithmetic is useful for understanding the Good as the Principle of Forms in Plato's Republic »

\section{BIBLIOGRAPHY}

BRISSON, L, Le meme et l'autre dans la structure ontologique du TIMEE de Platon, International Plato series 2, Academia Verlag, 1998.

YANG, M.-H.(1), “The Square Itself and 'Diagonal Itself in Republic 510d," Ancient Philosophy 19 (1999).

YANG, M.-H.(2), "The Relationship between Hypotheses and Images in the Mathematical Subsection of the Divided Line of Plato's Republic," Dialogue 44(2005).

YANG, M.-H.(3), “Arithmetical Numbers and Ideal Numbers in Plato's Philebus," Plato's Philebus, International Plato Series 26, Academia Verlag, 2010.

PLATO, The electronic Journal of the International Plato Society, n 11, 2011.

http://gramata.univ-paris1.fr/Plato/article104.html

(c) All rights of reproduction of any form reserved. 